\title{
The Integration of Samin Culture's Values in the Historical Learning
}

\author{
Ardian Eka Putra ${ }^{1}$, Djono $^{1}$, Sariyatun ${ }^{1}$ \\ ${ }^{1}$ Faculty of Teacher Training and Education \\ Universitas Sebelas Maret \\ E-mail: ardianeka92@gmail.com
}

\begin{abstract}
Learning in history plays a very important role, learning is clearly seen not only as a process of transferring ideas, but also the maturation process of learners to understand the identity, identity and character of the nation through the understanding of historical events. Character education in schools is developed through the integration of character values in subjects. In the process of planting identity and character into historical learning, we need to imitate the traditions and local wisdom of an ethnic group. Each ethnic group has its own values that are used as guidance in life. is no exception to the Samin community. They greatly uphold moral values and that is reflected in many aspects of life. Ethnic Samin not only emphasizes the morality aspect of the social relations of society solely but also on the relationship between man and his environment. Morality in the inter-communal relationship and with the environment around them they passed down through generations and local wisdom. Based on observations and observations made, historical learning has not been implemented optimally as the goal, this is because of the lack of cultural-based education cultivation in learners who from the beginning not included in the learning of history. Historical learning needs to integrate culturebased education (ethno pedagogic). The integration of cultural values of Samin in the learning of history aims to make history learning become varied and encourage students and educators to have a high attitude of solidarity. Through the historical learning approach is expected to assist in the mastery of models and learning materials. The purpose of this research is to develop the learning of history based on Samin cultural values.
\end{abstract}

Keywords: local wisdom; samin culture; historical learning

\section{INTRODUCTION}

The crisis that struck the Indonesian community from students to political elites indicates that religious and moral education developed in both school and college (college), has no impact on changes in Indonesian human behaviour. Even what is seen is so many Indonesian people are not coherent between words and actions. Such conditions, allegedly originated from what is produced by the world of education.

Surely this is not in accordance with the meaning and purpose of learning History. The subject of history has a strategic meaning in the formation of the character and civilization of a dignified nation and in the formation of Indonesian 
people who have a sense of nationality and love of the country. According to Permendiknas No. 22 Year 2006 Historical material:

1. Contain the values of heroism, exemplary, pioneering, patriotism, nationalism, and unyielding spirit that underlies the process of forming the character and personality of learners.

2. Contents of the civilization of nations, including the civilization of the Indonesian nation. The material is a fundamental educational material for the process of formation and creation of Indonesian civilization in the future.

3. Inculcating awareness of unity and brotherhood and solidarity to become the glue of the nation in facing the threat of disintegration of the nation.

4. Loaded with moral teachings and wisdom that is useful in overcoming multidimensional crisis faced in everyday life.

5. Useful to instil and develop a responsible attitude in maintaining the balance and environmental sustainability.

Character education in schools is developed through the integration of character values in subjects. Internalization of character values through the epistemology of learning (discussion, assignment, and the like). It departs from the assumption that the learning achievement of character values is not as an instructional effect but a nurturing effect. Character values are not content / content of subject matter that is learned in the cognitive domain but developed in the affective domain. This indicates the need for character values to be studied in the cognitive domain textually and contextually.

Content development in textual and contextual content of characters can be explored, elaborated and confirmed through the excavation of cultural values that grow and develop in ethnic or ethno pedagogic cultures. Because ethno pedagogic is the closest environment of the school is loaded with local wisdom values and become a tradition of inner wealth of the community who participated in colouring the formation of the character of learners in school. Cultural values that develop in a society will always be rooted in traditional wisdom that arises and develops in line with the development of society itself.

Based on the above description, the author tries to integrate the values of cultural values in learning history. More specifically on cultural values at the local level i.e. Blora district cultural values. With this integration, it is expected to increase the sense of solidarity of learners. Ironically very rarely do educators relate history learning to local wisdom. There are several factors that cause the problem to occur; first, the lack of in-depth knowledge of educators about local history; second, local history gets a narrow portion of learning; third, the unavailability of specific learning models on local history, especially the learning model based on cultural (local) values.

\section{RESEARCH METHODOLOGY}

The data analysis developed in this study uses historical analysis to determine the mapping of Samin cultural values, their relevance to historical learning to the present state. In describing the existing problems, this research uses literature research methods. According to Suwandi et.al (2016: 59-66), literature research is a method of 
research by conducting studies on books, literature, notes, reports, relating to problems to be solved in research.

\section{DISCUSSION}

The results of this literature will be described in two parts: first, an analysis of the cultural values of Samin, and the two integration of cultural values of Samin in the study of history.

\section{Cultural Values of Samin}

Tracing the richness and cultural diversity of the Indonesian nation seems endless. A variety of cultures grow into one of the local wealth and wisdom possessed by society which is a source of renewal for its environment. One form of local culture that exists and still holds a mystery to date is about the teachings, messages of behaviour and tradition that emerged in the community / community that developed in his time and become a reflection for the present generation. The growing teachings in society are part of the local wisdom that become solutions in his era and be learning materials to create effective solutions for the future. Local wisdom is the dissemination of traditional values of society that is full of wisdom and become a sticker for the creation of life and the next life.

Society of Samin is a cultural phenomenon, which has a unique and full of messages. The wong Samin's behaviour is impressed "as it should be," as if it does not recognize the existence of the state in their lives. Wong Samin is famous for his innocence, innocent and what it is to impress "dumb". Samin is synonymous with resistance. The doctrine of Samin is very popular as a symbol of popular resistance against the invaders.

Samin Surosentiko teaches his followers by way of lectures (sesoroh) at home or in the field. This is done because wong Samin cannot read and write. The main points of Samin teachings (Suyami, 2007: 29) include:

a. Agama iku gaman, Adam pangucape, man gaman lanang (religion is a weapon or live merchandise)

b. Aja drengki srei, tukar padu, dahpen, kemeren. Aja kutil jumput, bedhog nyolong (do not bother people, do not fight, do not like jealousy.) Do not like mengmbil belonging to others

c. Sabar lan trokal empun ngantos drengki srei, empun ngantos riyo sapada empun ngatos pek-pinepek, kutil jumput bedhog nyolong. Napa malih bedhog colong, napa milik barang, nemu barang teng dalan mawon kulo simpangi (do be patient and not arrogant, do not disturb people, do not arrogant, do not take the property of others, let alone steal, take the goods while encountering goods scattered in the street shunned)

d. Wong urip kudu ngerti uripe, sebab urip siji digawe salawase (living man must understand his life, because life is the same as the spirit only one and brought eternally forever)

e. Wong enom mati uripe nitip sing urip. Bayi uda nangis nger niku sukma ketemu raga. Dadi mulane wong niku mboten mati. Nek ninggal sandhangan niku nggih. Kedah sabar lan trokal sing diarah turune. Dadi 
wong, selawase dadi wong (when a young man dies, his spirit is entrusted to a living spirit, the crying baby is the sign of the meeting of the spirit with the body, so the spirit of the dead does not die, leaving only his clothes, the living man must be patient and tawakal for his descendants. So the spirit is not dead, but gathering with the living spirit, once the person does good, forever will be a good person)

f. Pangucap saka lima bundhelane ana pitu lan pangucap saka bundhelane ana pitu (like the one talking from the number five stops at number seven and the number nine also stops at the number seven, in other words is a gesture or symbol that humans in speaking should keep the mouth).

In essence Samin Surosentiko teachings concerning the values of human life. The teaching is used as a guide to behave and behave, in particular must always live well and honestly for offspring children. The teaching of Samin is a movement of meditation and the mobilization of psychotherapy forces to combat lust.

\section{Integration of Samin Cultural Values in Historical Learning}

Through the local history can be developed thinking skills of learners to be able to think critically, analytically and creatively and familiarize themselves in the process of scientific thinking so as to develop a sense of nationalism and patriotism. Historical learning is closely related to character education of a nation as an expression we often hear "a great nation is a nation that values the services of the heroes". Cultural values of Samin are integrated in history learning to become the basis for the development of culture-based education and the character of the nations.

The reality of the field we often encounter that the learning of history is often underestimated as a very boring subject for some people. This is not separated that there are still many teachers using lecture method or teacher centred. Historical history is not fully undertaken by the lecture process, but also has applied what is contained in the curriculum 2013 where learners are not just an object. Learning history has led to the student centred while the teacher only becomes a facilitator in learning.

Learning, as noted earlier is at the heart of the educational process. Learning becomes very important because in this activity there is a process of interaction between teachers as messengers and learners as the recipient of the message. With this view it appears that learning is a vehicle of transformation and generation of culture from generation to generation. The significance of this lesson provides an explanation that learning is a process that cannot be underestimated in the progress of the nation. In learning history, the important role of learning is clearly seen not only as the process of transferring ideas, but also the maturation process of learners to understand the identity, identity and personality of the nation through the understanding of historical events (Susanto, 2014: 56).

In addition, learning history also serves to awaken learners will be the process of change and development of society in the dimension of time and to build perspective and awareness of history in finding, understanding, and explain the identity of the nation in the past, present, and the future in the middle world change (Great, 2013: 56). In a simpler context, learning history as a sub-system of educational activities is a comparative effort in learning activities, which refers to organizing and organizing 
the teaching and learning environment so as to encourage learners to motivate learners to learn to develop themselves (Aman, 2011: 66).

A good historical lesson will shape the history of history. Understanding history is a trend of thinking that reflects the positive values of historical events in everyday life, so we become more wise in seeing and responding to various problems of life. Historical understanding gives us the clue to see a series of past events as a system of past acts in accordance with the soul of the clock, but has a set of educational values for the present and future life (Susanto, 2014: 36).

Based on Law Number 20 Year 2003 on National Education System Chapter II Article 3, education is a conscious effort to develop the potential of learners optimally. The conscious effort cannot be separated from the environment of the learners, especially from the cultural environment, because the learner is inseparable from the influence of his environment. Culture, which causes learners to grow and develop starting from the cultural environment in the nearest environment. If learners become alien to the culture that exists in the environment then very susceptible to the influence of outside culture and tend to accept outside culture without the process of consideration.

The integration of cultural values of Samin is done through the introduction, implementation, giving examples of cultural values that become the cultural basis of a local wisdom. The values developed come from the views of life, religion, culture and values that are relevant to be implemented in today's conditions. Awakening learners about the importance of Samin cultural values in everyday life has developed the potential of learners as human beings who care about local wisdom. Developing Samin cultural values for contemporary life has instilled the soul of the learner's responsibility as the next generation of the nation.

In essence, the integration of Samin cultural values in History learning is part of the self-development and school culture environment. Integration of local wisdom values (cultural values of Samin) has been contained in the curriculum of 2013, syllabus and Learning Program Plan (RPP). Integration of Samin cultural values in learning History is contained in the subject of Indonesian national movement. Samin cultural values are taken through the process of Basic Competence Review (KD) to determine the cultural values of Samin. Shows the relevance of KD with Samin cultural values and Indicators of achievement of competence to determine the values developed. From the results of the analysis will give birth to a model of learning for learners actively that allows learners have the opportunity to internalize value and show it in behaviour.

\section{CONCLUSION}

Currently, the learning system has undergone many significant changes. For example from the learning model that is "teacher centred" turned into "student centred". More learning models to learners have taken precedence. This, in addition to training the independence of learners in learning, can also improve a strong memory of the given subject matter. The learning process by changing the new learning model is one of those efforts. Samin's cultural values education to develop and strengthen personal potential and also filter out outside influences can ultimately shape the character of learners that reflect the values of local wisdom. Integration of 
cultural values of Samin is done through a series of teaching and learning activities (learning model) either through learning activities or a series of self-development conducted within the school and outside the school.

\section{REFERENCES}

[1] Alamsyah. 2015. Eksistensi Dan Nilai-Nilai Kearifan Komunitas Samin Di Kudus Dan Pati. Jurnal HUMANIKA Vol. 21 No. 1 (2015)

[2] Aman, (2011). Model Evaluasi Pembelajaran Sejarah. Yogyakarta: .

[3] Haryanti, J.K. 2014. Kearifan Lokal Pendukung Kerukunan Beragama Pada Komunitas Tengger Malang Jatim. Jurnal Analisa, Vol. 21 No.2.

[4] In Purnamasari dan Wasino, 2011. Pengembangan Model Pembelajaran Sejarah Berbasis Situs Sejarah Lokal di SMA Negeri Kab. Temanggung. Jurnal Paramita, Vol. 21 No.2, Juli 2011.

[5] Koencoroningrat.2007. Manusia dan Kebudayaan di Indonesia. Jakarta: Djambatan

[6] Mukodi \& Afid,B. 2016. Islam Abangan Dan Nasionalisme Komunitas Samin Di Blora. Jurnal Penelitian Sosial Keagamaan, Vol. 24 No. 2, November 2016.

[7] Status, economic determinism and monocausality: more on the Samin. Bijdragen tot de Taal-, Land- en Volkenkunde 133 (1977), no: 2/3, Leiden, 350-354.

[8] Susanto Ahmad.(2005). Belajar dan Pembelajaran. Jakarta: Rineka Cipta.

[9] Suyami, ed. (2007). Kearifan Lokal di Ligkungan Masyarakat Samin Kabupaten Blora Jawa Tengah. Yogyakarta: Kantor Pariwisata dan Kebudayaan Kabupaten Blora.

[10] The Samin movement and millenarism. Bijdragen tot de Taal-, Land-en Volkenkunde 132 (1976), no: 2/3, Leiden, 249-266.

[11] The Samin movement. Bijdragen tot de Taal-, Land- en Volkenkunde 125 (1969), no: 2, Leiden, 207-240. 